\title{
Utilizing a Fuzzy Inference System (FIS) and Modified Analytical Hierarchical Analysis for Forest Road Network Planning in Afforested Lands
}

\author{
Ender Buğday ${ }^{1}$, Halil Barış Özel²* \\ ${ }^{1}$ Çankırı Karatekin University, Faculty of Forestry, Department of Forest Engineering, Çankırı, Turkey \\ ${ }^{2}$ Bartın University, Faculty of Forestry, Department of Forest Engineering, Agdaci Campus, Bartın, Turkey
}

Received: 4 March 2018

Accepted: 28 March 2018

\begin{abstract}
Afforestation activity needs serious feasibility in as much as it is a work of establishing a new facility. Moreover, the process of selecting the land to be afforested; determining site conditions; selecting suitable tree species, provenance, and clones; the planting or sowing techniques; and planning of the environmental transport network are all costly. Determining suitable areas for environmental road network installation, which has an important place in afforestation areas, is discussed in this study. In this context, characteristics of an afforestated area have been evaluated by virtue of the fuzzy inference system (FIS) and modified analytical hierarchical analysis (M-AHP) methods on a sample area established as an afforestation area. The main objective of this study is planning in a way that is sensitive to nature and strives for ecological balance on environmental forest road networks for forested and afforested areas by utilizing multiple decision support methods with a view to realizing maintenance on afforestation areas in short- and long-term processes. A total of eight factors were determined in the study. The best twelve models, obtained as a result of analyses carried out with these factors, are presented. The success of the models was evaluated with receiver operating characteristic (ROC) analysis and the best model was obtained by M-AHP, which was Model $4_{\mathrm{M}-\mathrm{AHP}}$ with $71.2 \%$ area under curve (AUC) value. We observed that the model obtained through the M-AHP method is more successful in on-site road network planning during the phase of creating the afforestation projects.
\end{abstract}

Keywords: fuzzy inference system, M-AHP, afforestation, environmental forest road network

*e-mail: halilbarisozel@gmail.com 


\section{Introduction}

Forests have become an undeniable reality as a source of life, which is important-complicated for mankind and other living things and which is a guarantee for the future. Reforestation activities of non-forest and deforested areas are also increasing daily [1]. Deforested areas destructed due to natural disasters such as fire and tornado, and anthropogenic disasters are reforested annually [2-5]. Moreover, afforestation increases the amount of forest covering the land of countries around the world. However, much as afforestation work continues, the annual amount of afforested area does not equal the deforested areas [6]. The change in the amount of the forest-covered lands compared to the previous year provides important clues as to forest asset of countries. According to FAOSTAT (2018), net forest conversion is approximately nine million hectares, in line with the data of 2015 [6]. Afforestation activities continuous dynamically in many parts of the world. Afforestation activities have lots of benefits and effects such as ecological restoration, enhancement of water retention capacity, erosion control, increasing carbon sequestration potential, and reducing the albedo effect $[4,7-10]$.

Re-afforestation activities are projected because they can include entire actions to be carried out in an area in the long term. Every stage of re-afforestation activities must be calculated and examined very seriously because re-afforestation works are very costly and laborintensive, and also because they are "long-term" works that are "beneficial for future generations" [4, 11-13].

There are numerous studies in the literature as regards each part of afforestation activities. Economic evaluation of selected tree species [11], determining the relationships between ground and tree species to be selected [14], adaptation of selected tree species [15], identifying the most suitable areas for afforestation [16-18], evaluating the contribution of the afforestation studies to the social and economic structure of the people living in the vicinity of afforestation activities $[19,20]$, and similar studies can be shown as examples of the scientific approach to afforestation activities from different angles. As a matter of fact, the success levels of the afforestation activities are tried to be increased by virtue of simulations made on the afforestation areas currently in our day $[10,21,22]$.

Our study discusses planning road networks in afforested areas, which are important tools used for afforestation activities and which is an infrastructure facility at the same time. The routes of these roads, which will be used as a "service road" while the afforestation activities continue and which will be used as a "forest road" after the afforestation activities are achieved, should be clarified during the projecting phase. The construction of forest roads is very costly [23-26], so it is necessary to determine the suitable places in the road network planning during the afforestation project phase in order to minimize the general costs on the forest. On the other hand, forest road construction in the forest area seriously damages the forest and environment [27-31]. This study has been carried out based on the hypothesis that the road network to be planned and applied during the afforestation works will be less harmful to the environment compared to a road network to be built in a forested area.

In this context, after the evaluation of the area to be afforested as regards the exclusive features thereof, it is necessary to determine the most suitable areas for the routes indicated as "service road" in afforestation projects. It is envisaged that the road route to be planned will vary based on the different features of the land structure, soil characteristics and as such the variety of trees to be planted. In fact, in forest road planning; numerous "multi-criteria evaluation methods" are utilized in our day in order to evaluate all of the specified features together and select the most appropriate one among the cited different alternatives [32-39].

It was targeted to determine the most suitable areas for the road network by evaluating the multicriteria in afforestation areas in this study. In this way, in the following years, the new forests resulting from afforestation areas will be prevented from damage

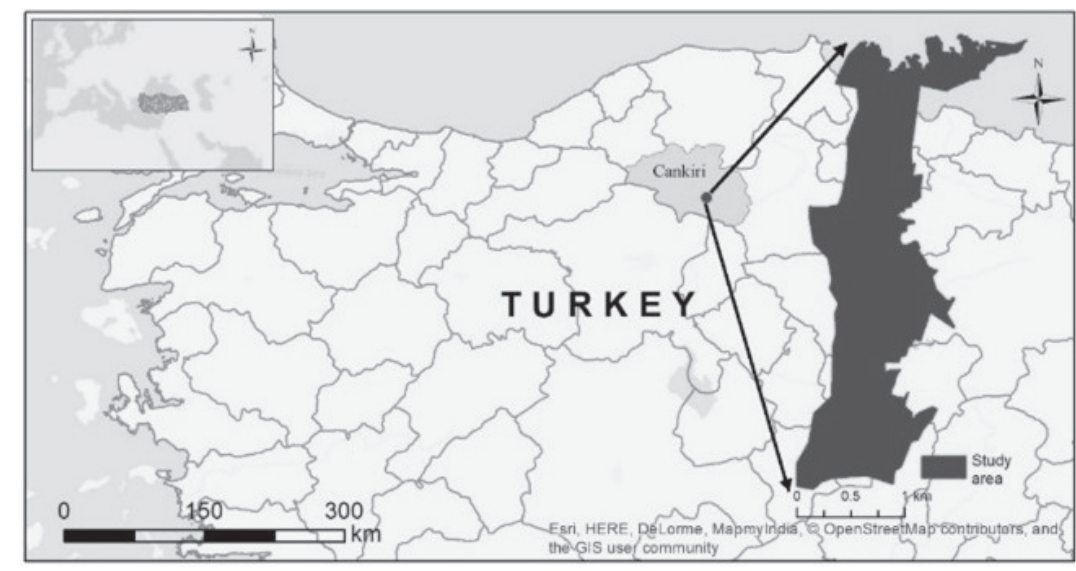

Fig. 1. Location of study area. 
by new road construction due to reasons such as maintenance, production, and protection. To this end, predicting suitable areas for planning a road network in the afforestated area was carried out by virtue of fuzzy-logic and modified analytical hierarchical analysis methods. In this way, both multi-criteria evaluation methods will be used for road planning, and the success of the two different methods will be compared in this study.

\section{Material and Methods}

The study area is the province of Çankırı in northern Turkey between 40³4'37', 40³3'05' north

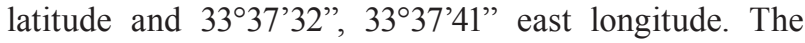
study area is approximately 330 ha and its location is shown in Fig. 1. The non-forest area, which is located in the administrative boundaries of Doğantepe village of Çankırı and is described as "empty land," has been allocated to the General Directorate of Forestry to be reforested in 2015 through the General Directorate of National Real Estate [40]. The area is located in the 404 section of Çankırı Forest Management Directorate's Çankırı Forest Management Sub-District Directorate and the afforestation project has been prepared and implemented by the Afforestation and Soil Conservation Sub-District Directorate [40].

Factors affecting forest road network planning also are valid for the road network to be planned in the afforested areas. Acting in line with both short- and long-term purposes is important for successful planning. Eight factors were analyzed in terms of planning in this study. These factors include the following: elevation (E), slope (S), lithology (L), tree species (TS), topographic wetness index (TWI), stream power index (SPI), plan curvature $(\mathrm{Kc})$, and profile curvature $(\mathrm{Kp})$. The factors are provided in Fig. 2.

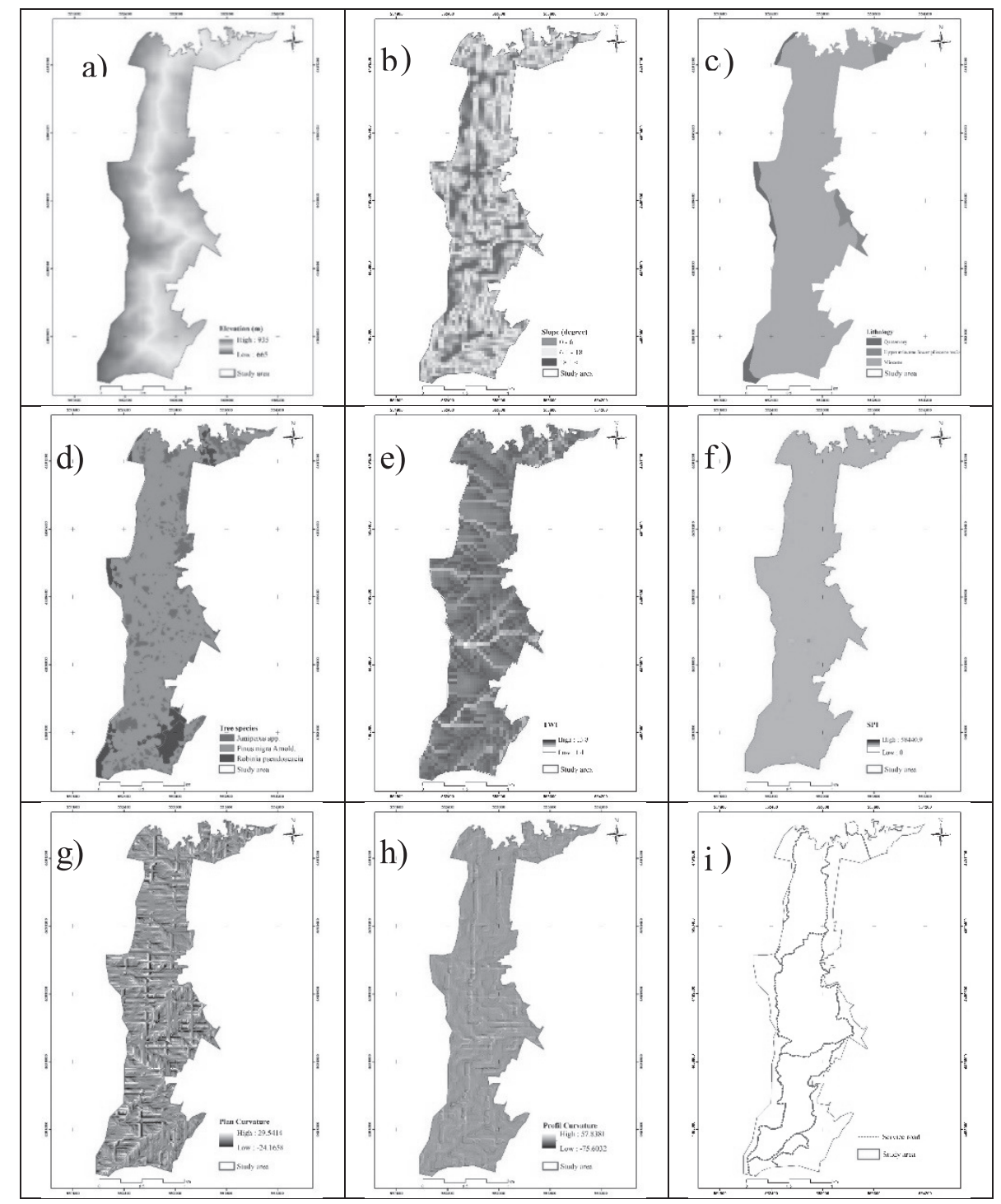

Fig. 2. Road network planning factors in an afforested area: a) Elevation (E), b) Slope (S), c) Lithology (L), d) Tree species (TS), e) Topographic Wetness Index (TWI), f) Stream Power Index (SPI), g) Plan curvature (Kc), h) Profile curvature (Kp), i) current service road. 
Elevation, which is the first factor used in this study, is an important factor in the planning of forest roads due to its negative effects on temperature, precipitation type, and soil characteristics. The area of each community was distributed over three elevation classes (Fig. 2a). The slope is a significant factor inasmuch as it directly affects both the working time and the construction cost. The average slope of the study area is 14 degrees and the slope is grouped into three classes as $0-6,6.1-18$, and $18.1<$ (Fig. 2b). Lithology is considered a factor that affects the cost of forest road construction inasmuch as it reveals the features of the bedrock. In this study, lithology was evaluated in two groups as with soft and hard features (Fig. 2c). Tree species is another important factor in forest road planning. It affects the forest road density and designs directly based on the fact that the silvicultural maintenance works may frequently vary, especially if tree species are of the same age and of different ages (Fig. 2d). Topographic wetness index (TWI) (Formula 1) is widely utilized in order to determine the location and size of water-saturated areas at the topographic level [41]. The study area TWI is shown Fig. 2e).

$$
\begin{gathered}
T W I=\ln \left(\frac{A_{S}}{\tan \beta}\right) \\
\mathrm{A}_{\mathrm{s}}=\text { Specific basin area } \\
\mathrm{B}=\text { Incline of slope }
\end{gathered}
$$

Stream Power Index (SPI) (Formula 2) is defined as the ability of the flowing water to cause erosion in the topography considering the assumption that the current (q) is proportional to the specific basin area (As) [41]. It is shown in Fig. 2f).

$$
\begin{gathered}
S P I=A_{S} \times \tan \beta \\
\mathrm{A}_{\mathrm{s}}=\text { Specific basin area } \\
\mathrm{B}=\text { Incline of slope }
\end{gathered}
$$

Plan curvature $(\mathrm{Kc})$, (Formula 3) slope direction along a specific topographic elevation is defined as the change in (contour line) by virtue of the equation provided below [42]. It is shown in Fig. $2 \mathrm{~g}$ ).

$$
\begin{gathered}
K_{C}=\frac{\frac{\partial_{Z}^{2}}{\partial_{x^{2}}}\left(\frac{\partial_{z}}{\partial y}\right)-2\left(\frac{\partial_{Z}^{2}}{\partial x \partial y}\right)\left(\frac{\partial_{z}}{\partial x}\right)\left(\frac{\partial_{z}}{\partial y}\right)+\frac{\partial_{z}^{2}}{\partial y^{2}}\left(\frac{\partial_{z}}{\partial x}\right)^{2}}{\left[\left(\frac{\partial_{z}}{\partial x}\right)^{2}+\left(\frac{\partial_{z}}{\partial y}\right)^{2}\right]^{\frac{3}{2}}} \\
\mathrm{z}=\text { Topographic Elevation }
\end{gathered}
$$

Profile curvature (Kp, curvature of the slope profile; Formula 4) expresses the velocity of flow in the surface of the water and the transport of the sediments along the slope, thus revealing the erosion that develops by expressing the rate of curve change. If the profile component is negative, it indicates concave (pit) structure and if it is positive it indicates (hill) structure. $\mathrm{Kp}$ is defined by the following equation as the slope curve change in slope downhill [42] (Fig. 2h):

$$
\begin{gathered}
\left(\frac{\partial_{z}^{2}}{\partial_{x^{2}}}\right)=\frac{z_{6}-2 z_{5}+z_{4}}{\partial_{x}^{2}} \\
\left(\frac{\partial_{z}^{2}}{\partial_{y^{2}}}\right)=\frac{z_{2}-2 z_{5}+z_{8}}{\partial_{y}^{2}} \\
\left(\frac{\partial_{z}^{2}}{\partial_{x} \partial_{y}}\right)=\frac{-z_{1}+z_{3}+z_{7}-z_{9}}{4 \partial_{x}^{2}} \\
K_{p}=\frac{\frac{\partial_{z}^{2}}{x^{2}}\left(\frac{\partial_{z}}{\partial y}\right)^{2}+2\left(\frac{\partial_{z}^{2}}{\partial x \partial y}\right)\left(\frac{\partial_{z}}{\partial x}\right)\left(\frac{\partial_{z}}{\partial y}\right)+\frac{\partial_{z}^{2}}{\partial_{y^{2}}}\left(\frac{\partial_{z}}{\partial y}\right)}{\left(\left[\left(\frac{\partial_{z}}{\partial x}\right)^{2}+\left(\frac{\partial_{z}}{\partial y}\right)^{2}\right]\left[\left(\frac{\partial_{z}}{\partial x}\right)^{2}+\left(\frac{\partial_{z}}{\partial y}\right)^{2}+1\right]\right)^{\frac{3}{2}}} \\
Z=\text { Topographic Elevation }
\end{gathered}
$$

The roads used as a service road in the afforestated area were transferred to digital environment by Google Earth. The current service road length was calculated as $14.8 \mathrm{~km}$ (Fig. 2i). Elevation and slope were determined by forming contour lines with $5 \mathrm{~m}$ intervals on the base obtained from the ASTER-GDEM digital elevation model. Generally, in processing spatial data obtained for different purposes we used various GIS software such as ArcGIS, NetCAD, and MapInfo [43-47]. In this study all factors were processed from the databases of the related forestry unit and transferred to NetCAD-GIS software and the calculations were made.

Eight factors were evaluated by virtue of two methods in the study. The first preferred method was the modified analytical hierarchy process (M-AHP) method. Analytical hierarchy process (AHP) is a math-based GIS-compatible and multidisciplinary decision method utilized in various fields and also in the planning of routes, construction, and maintenance of roads and railways and subways [48-52]. At the same time, AHP is also preferred and used in forestry studies [53-58]. In the AHP method, analysis can be subjective inasmuch as the factors are limited through user-specified constraints [46]. As such, the M-AHP approach was adopted to get rid of this subjective situation [59]. M-AHP is better than the classic AHP approach inasmuch as it does not need an expert opinion, normalizes the factors, and makes the criterion comparison more successful at the decision-making stage $[46,59,60]$. Based on this reason, the M-AHP method was preferred in this study.

The second preferred method in the study was the fuzzy logic (Mamdani) method in the FIS. Fuzzy logic, discovered by Zadeh [61], is very successful in the solution of complex problems and is widely used [61]. Fuzzy logic is a mathematical methodology in which variable values are not used as 0 or 1 and interval values are also not taken into account [59, 62-64].

Fuzzy logic (Mamdani) and M-AHP methods and NetCAD software were used in evaluating the factors in this study as they are also utilized in other different studies [47]. The workflow of this work is given in Fig. 3. 


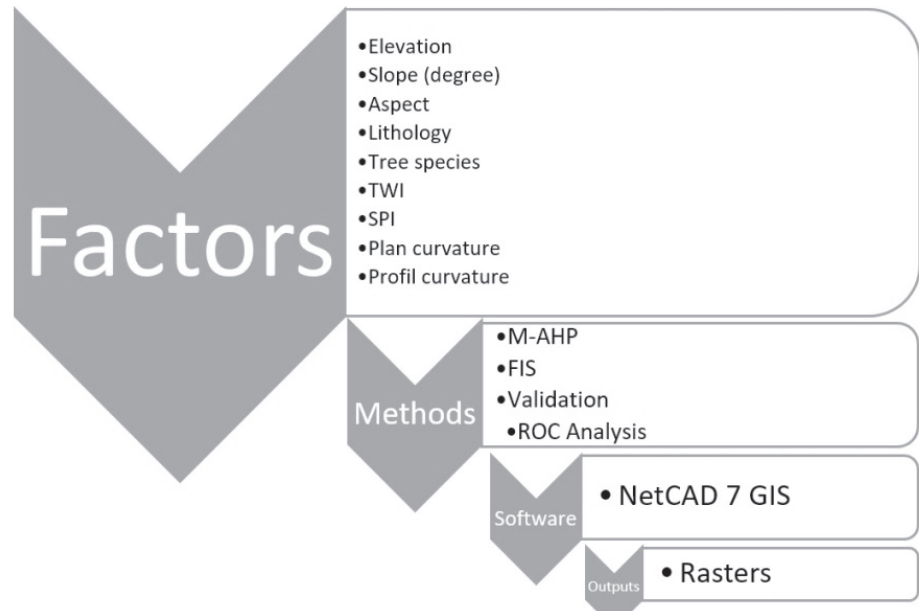

Fig. 3. Flowchart of suitability mapping in an afforested area.

\section{Results and Discussion}

Twelve models were developed according to the fuzzy inference system (FIS) and M-AHP. Six of these models were produced with M-AHP and the others with FIS approaches.

The models produced with FIS are:

- Model $1_{\text {FIS }}$ includes slope (degree), tree species, SPI, and TWI factors.

- Model 2 FIS includes slope (degree), SPI, elevation, and tree species factors.

- Model $3_{\mathrm{FIS}}$ includes elevation, tree species, SPI, and TWI factors.

- Model $4_{\mathrm{FIS}}$ includes slope (degree), elevation, SPI, tree species, and plan curvature factors.

- Model $5_{\text {FIS }}$ includes slope (degree), elevation, SPI, tree species, and lithology factors.

- Model $6_{\mathrm{FIS}}$ includes slope (degree), SPI, tree species, lithology, and profile curvature factors.

The models produced with M-AHP are:

- Model $1_{\mathrm{M}-\mathrm{AHP}}$ includes slope (degree), tree species, SPI, and TWI factors.

- Model $2_{\mathrm{M}-\mathrm{AHP}}$ includes slope (degree), SPI, elevation, and tree species factors.

- Model $3_{\mathrm{M}-\mathrm{AHP}}$ includes elevation, tree species, SPI, and TWI factors.

- Model $4_{\mathrm{M}-\mathrm{AHP}}$ includes slope (degree), elevation, SPI, tree species, and plan curvature factors.

Table 1. Scores of the factors related to the model generated by the M-AHP method.

\begin{tabular}{|c|c|c|c|c|c|}
\hline Factor & Classification & Amount & Factor & Classification & Amount \\
\hline \multirow{3}{*}{ Elevation } & $665-750$ & 5 & \multirow{5}{*}{ TWI } & $1.38-3.86$ & 5 \\
\hline & $750-830$ & 3 & & $3.86-6.35$ & 5 \\
\hline & $830-935$ & 1 & & $6.35-8.83$ & 3 \\
\hline \multirow{3}{*}{ Slope (degree) } & $0-6$ & 5 & & $8.83-11.32$ & 1 \\
\hline & $6-18$ & 3 & & $11.32-13.81$ & 1 \\
\hline & $18-23$ & 1 & \multirow{5}{*}{ Plan curvature } & -0.9 & 5 \\
\hline \multirow{2}{*}{ Lithology } & 1-Soft & 3 & & -0.89 & 5 \\
\hline & 2-Hard & 1 & & -0.9 & 3 \\
\hline \multirow{5}{*}{ Tree species } & 1- Juniperus spp. & 1 & & -0.89 & 3 \\
\hline & & & & $0.5-1.4$ & 1 \\
\hline & 2- Pinus nigra Arnold. & 3 & \multirow{5}{*}{ Profil curvature } & $-97.09-75.00$ & 5 \\
\hline & & & & $75.00-250.00$ & 5 \\
\hline & 3- Robinia pseudoacacia & 1 & & $250.00-425.00$ & 3 \\
\hline \multirow{2}{*}{ SPI } & $-62,303.35-0$ & 3 & & $425.00-600.00$ & 1 \\
\hline & $-62,303.35-58,440.90$ & 1 & & $600.00-772.32$ & 1 \\
\hline
\end{tabular}


- Model $5_{\text {M-AHP }}$ includes slope (degree), elevation, SPI, tree species, and lithology factors.

- Model $6_{\mathrm{M}-\mathrm{AHP}}$ includes slope (degree), SPI, tree species, lithology, and profile curvature factors.

The classification and scoring of the factors used in the models are given in Table 1.

According to the M-AHP approach used in this study, elevation values ranged between $665 \mathrm{~m}$ and $935 \mathrm{~m}$ (Table 1) and are classified into three elevation groups. The highest score with 5 points was given to areas with low altitude because of their lower cost and faster accessibility advantages. In the study, the slope was evaluated in three different groups. The highest value of 5 was given slope areas in this classification since the increase in slope value affects both cost and productivity.

Lithology, Quaternary, and Miocene were classified in two groups as soft and hard ground in the study and they were given the highest score of 3 in the group with soft characteristics in terms of working more efficiently in road construction and reducing cost, in addition to benefiting root growth. The tree species factor was derived from the map of tree species distribution in the afforestation project [40]. Scoring was done according to three different tree species that were planned to plant in the afforestation area. Three points that were the highest rating for the classification were given Pinus nigra Arnold, since it is a widespread species with the high economic value of raw wood materials and more successful in afforestation.

The topographic wetness index (TWI) is an important factor in terms of the impact of topography on the hydrological process and therefore the ability to express soil moisture [65]. This factor has been chosen because soil moisture tends to be more at $0-15 \mathrm{~cm}$ depth in the forest roads [66]. TWI was evaluated in five different groups. The highest score with 5 points was given. Stream power index (SPI) is a factor

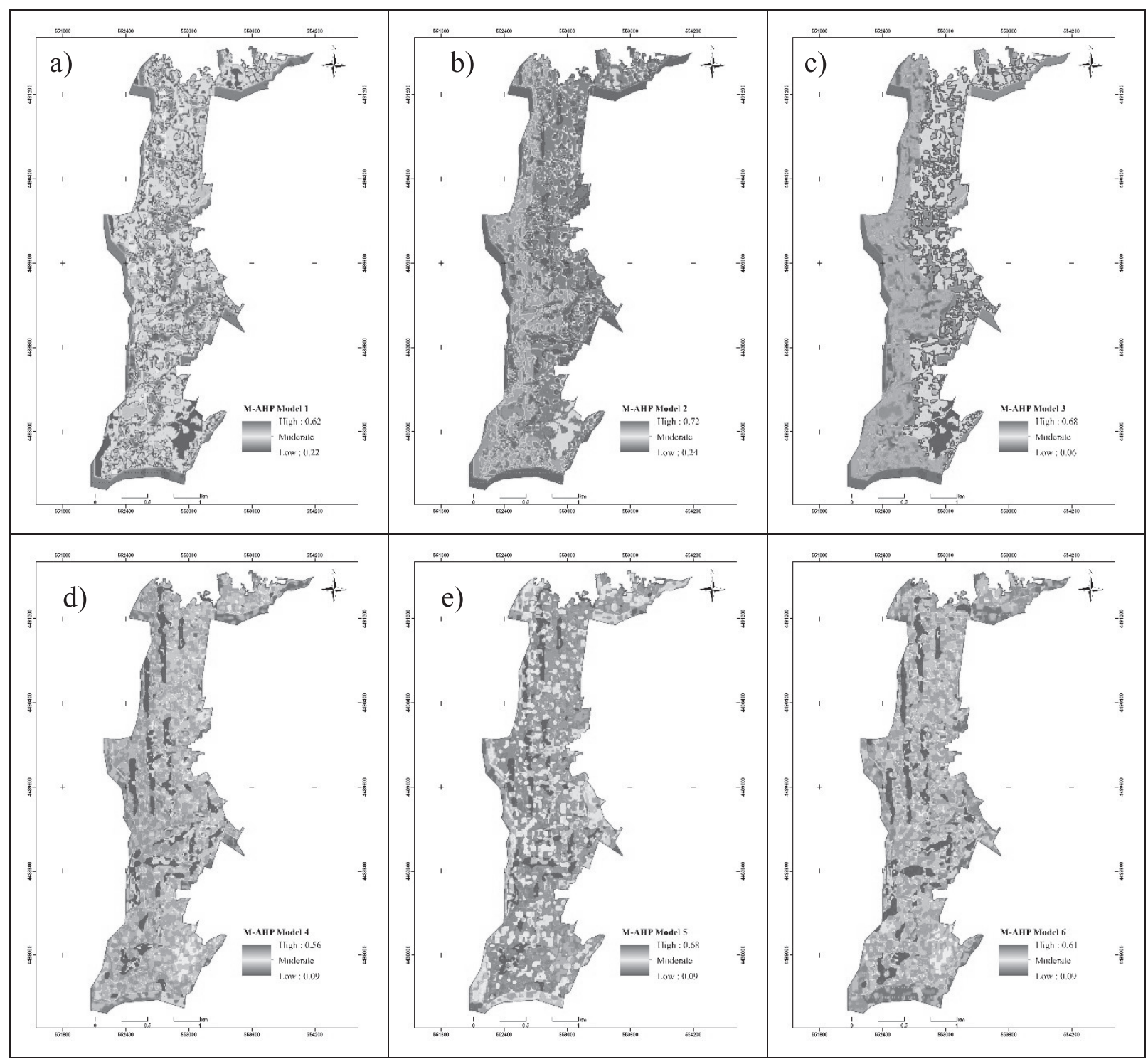

Fig. 4. Models obtained according to the M-AHP approach: a) Model $1_{\text {M-AHP }}$, b) Model $2_{\text {M-AHP}}$, c) Model $3_{\text {M-AHP }}$, d) Model $4_{\text {M-AHP }}$, e) Model $5_{\text {M-AHP }}$, f) Model $6_{\text {M-AHP }}$ 


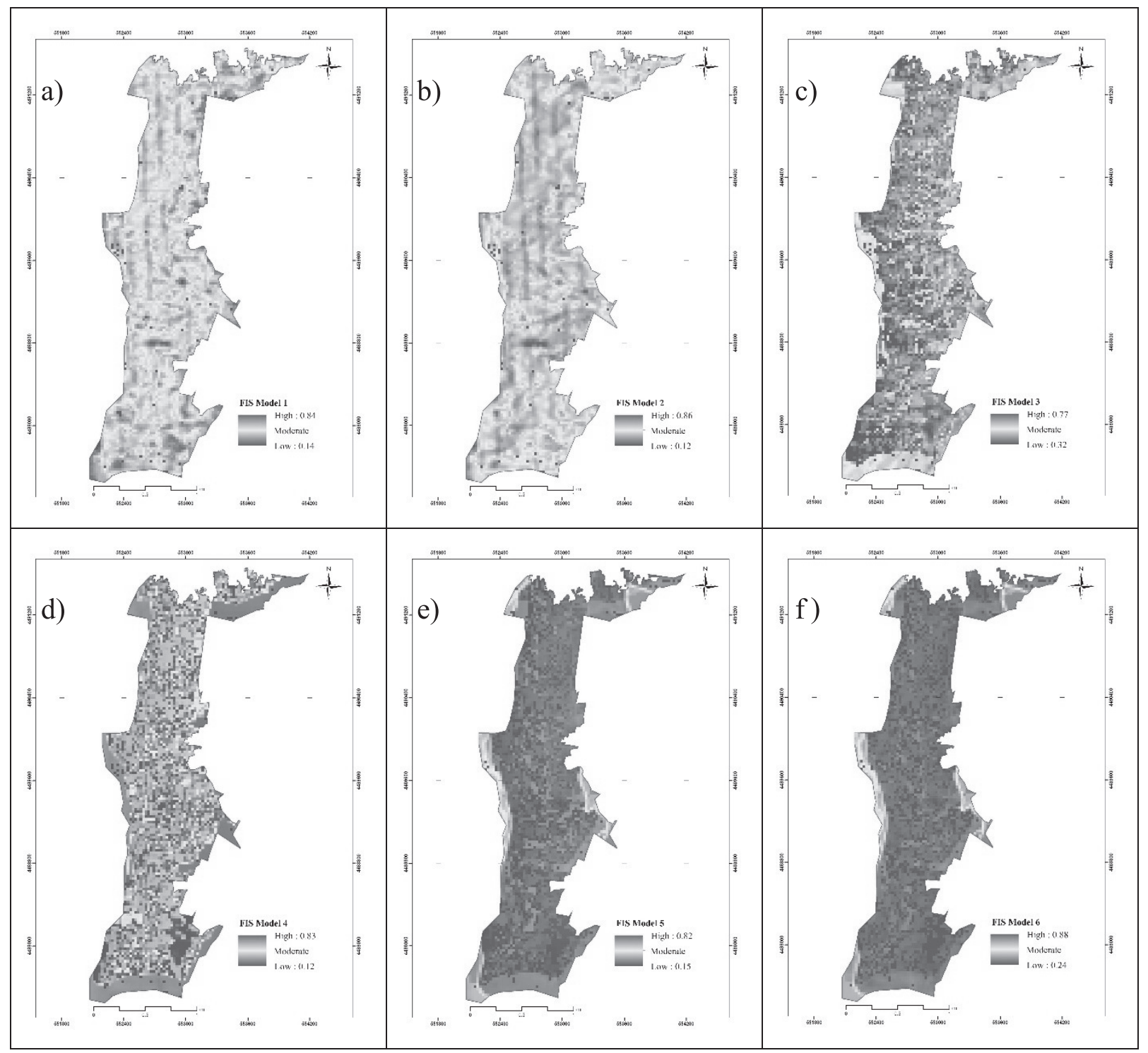

Fig. 5. Models obtained according to the FIS approach: a) Model $1_{\mathrm{FIS}}$, b) Model $2_{\mathrm{FIS}}$, c) Model $3_{\mathrm{FIS}}$, d) Model $4_{\mathrm{FIS}}$, e) Model $5_{\mathrm{FIS}}$, f) Model $6_{\text {FIS }}$.

used to express the erosive power of the stream [67]. SPI has divided two groups and the highest score with 3 points were given. Curvatures (plan and profile) were considered a factor in the study because it represents concave or convex land in forest road construction. Curvatures (plan and profile) were evaluated in five different groups. The highest scores were given 5 points.

The other method used in this study is the FIS approach, which integrates with NetCAD 7 GIS software.

This approach features the database used and the membership functions to which these factors were assigned. The rules were based on whether these factors are low or high. The analysis results obtained with these factors were obtained as output data. Factors used in this study were inputs of the FIS method. Rasters were the outputs of generated models. All entries were defined as triangular membership functions in fuzzy sets. Models obtained according to the M-AHP and FIS approach were given in Figs 4 and 5.

In this study, the validation of the successful measurements of the models obtained according to the M-AHP and FIS approaches was made according to receiver operating characteristic (ROC) analysis $[39,67,68]$, and area under curve (AUC) values were calculated.

The success rates of the models obtained according to the M-AHP and FIS approach are given in Figs 6 and 7.

According to the M-AHP method, models' successes were found to be: AUC-Model $1_{\mathrm{M}-\mathrm{AHP}}=70.2 \%$, AUCModel $2_{\mathrm{M}-\mathrm{AHP}}=69.3 \%$, AUC-Model $3_{\mathrm{M}-\mathrm{AHP}}=68.5 \%$, AUC-Model $4_{\mathrm{M}-\mathrm{AHP}}=71.2 \%$, AUC-Model $5_{\mathrm{M} \text {-AHP }}=69.7 \%$, and AUC-Model $6_{\mathrm{M}-\mathrm{AHP}}=69.6 \%$.

According to the FIS method, models' successes were found to be: AUC-Model $1_{\mathrm{FIS}}=64.5 \%$, 
AUC-Model $2_{\mathrm{FIS}}=64.3 \%$, AUC-Model $3_{\mathrm{FIS}}=63.8 \%$, AUC-Model $44_{\mathrm{FIS}}=70.7 \%$, AUC-Model $5_{\mathrm{FIS}}=66.3 \%$, and AUC-Model $6_{\mathrm{FIS}}=62.7 \%$.

It is important to increase the success of afforestation efforts, which are costly for increasing forests in the global world as well as reducing sustainable activities costs to reasonable levels. Updating the inadequate road network and frequent maintenance and repair of infrastructures could be hindered by determining road networks, which are basic infrastructure facilities,

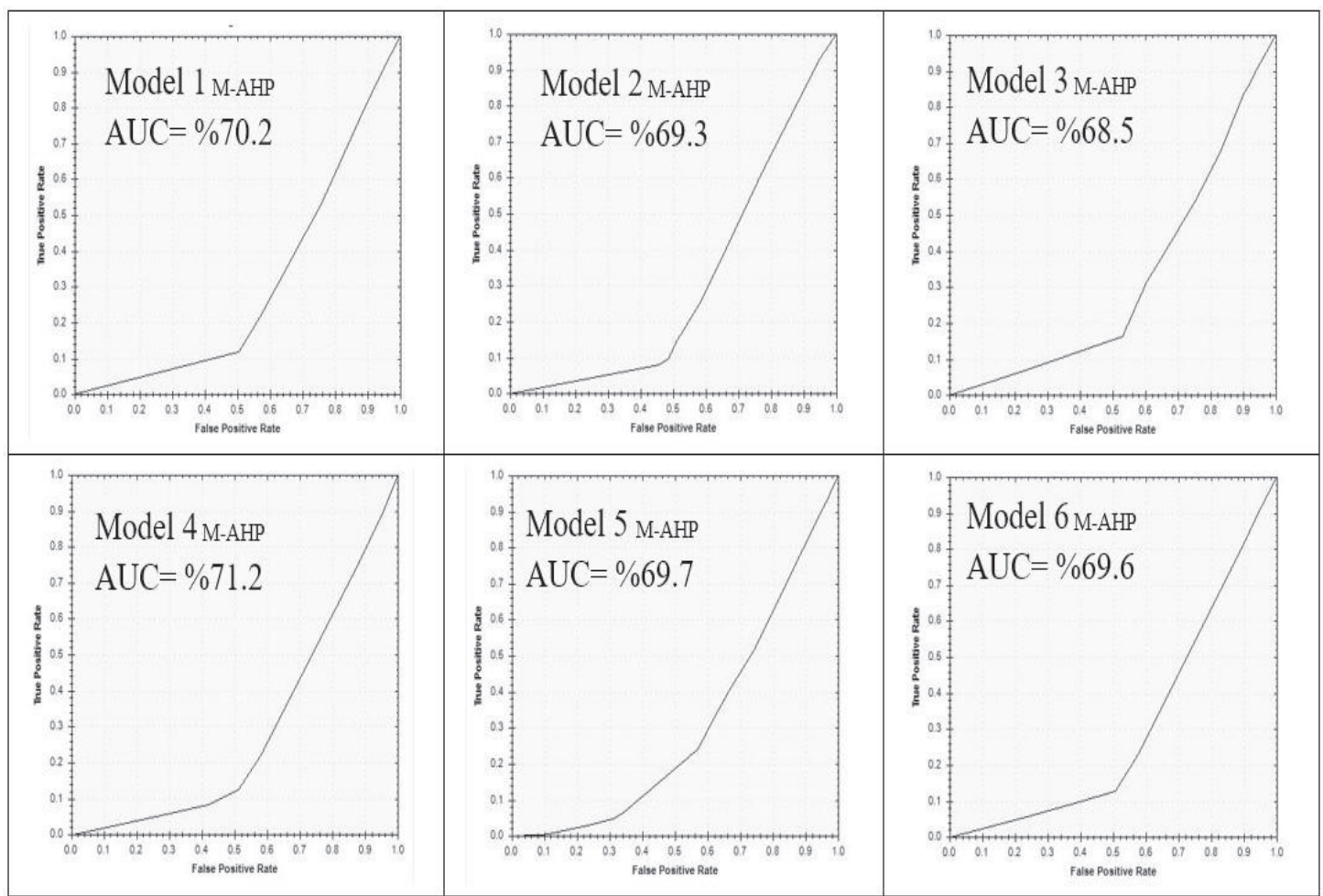

Fig. 6. Success rates of the models obtained according to the M-AHP approach.

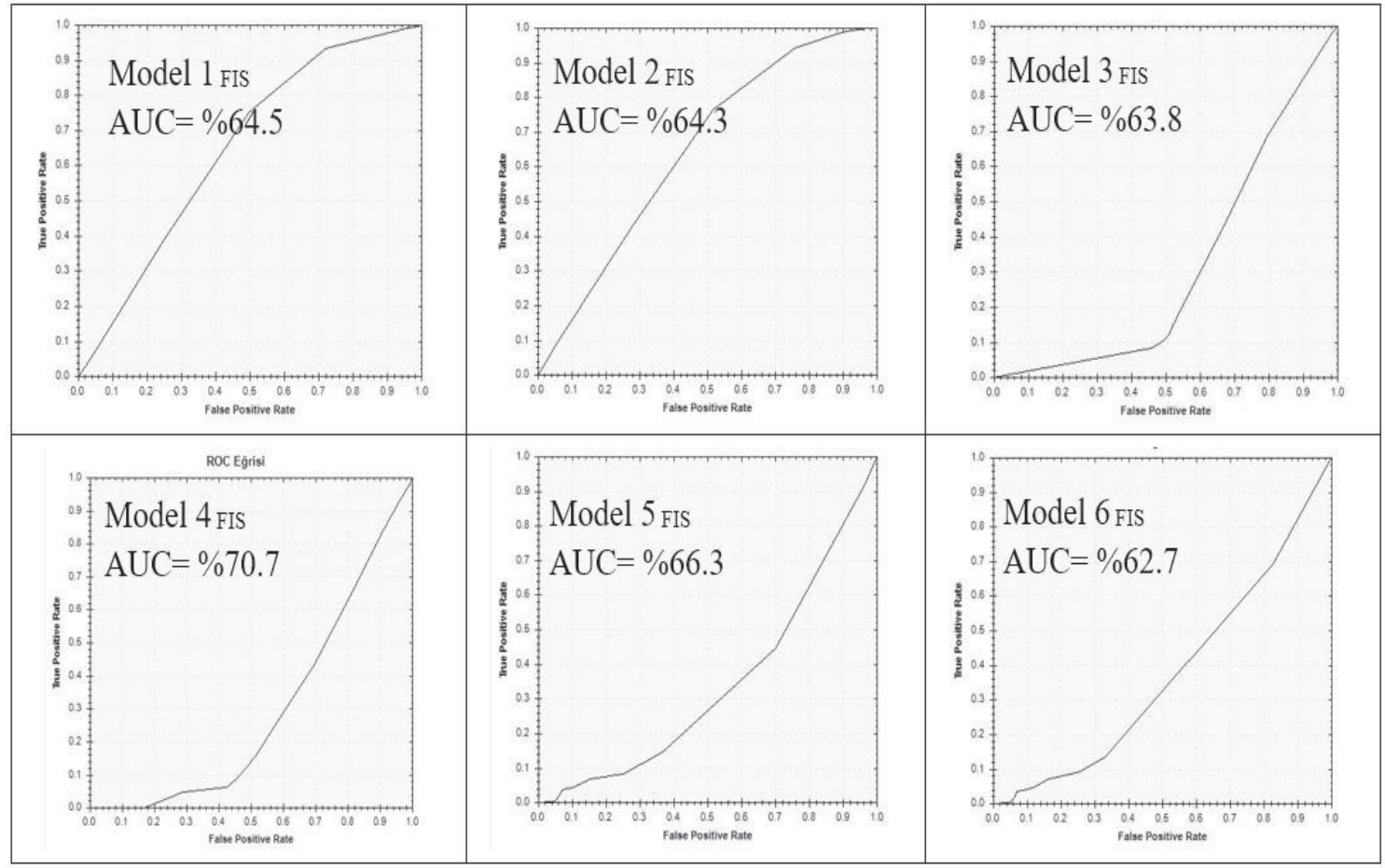

Fig. 7. Success rates of the models obtained according to the FIS approach. 
at the planning stage of afforestation activities. The M-AHP and FIS approach utilized in this study were tested on eight factors of the afforestation area and the Model $4_{\mathrm{M}-\mathrm{AHP}}$ (AUC 71.2\%), which was determined to be the most successful model in line with the obtained results. When these results and the results of [46] were compared, the M-AHP approach was observed to be more successful than the FIS approach in both studies. In the study of [69] in which M-AHP approach is compared with GLM, GAM, and MARS approach, it was also indicated that M-AHP is a more successful approach. In this study, the most suitable areas were determined by evaluating the factors affecting road planning $[39,60]$.

\section{Conclusions}

Diversification of the factors utilized in these and similar studies and evaluation of the factors with different approaches and even the determination of the successes of the approaches on the same factors are significant as regards the development of decision support systems. Furthermore, taking into consideration the characteristics of the afforestation area and using GIS systems and M-AHP effectively in planning the road network to be constructed will lead to the establishment of a dynamic infrastructure. Rational and effective plans can be created within the framework of sustainable forest management in this way.

\section{Acknowledgements}

Thanks to NetCAD Software Inc. and its employees for providing NetCAD 7.6 GIS software support for this study.

\section{Conflict of Interest}

The authors declare no conflict of interest.

\section{References}

1. FAO. Global forest resources assessment 2015 How are the world's forests changing? Second Edition. Food and Agriculture Organization of the United Nations Publisher, Italy, 54-, 2016.

2. BARBIER E.B. Natural barriers to natural disasters: replanting mangroves after the tsunami. Frontiers in Ecology and the Environment, 4 (3), 124, 2006.

3. BENSEL T. Fuelwood, deforestation, and land degradation: 10 years of evidence from Cebu Province, The Philippines. Land Degradation \& Development, 19 (6), 587, 2008.

4. ÇALIŞKAN S., BOYDAK M. Afforestation of arid and semiarid ecosystems in Turkey. Turkish Journal of Agriculture and Forestry, 41 (5), 2017.

5. RYU S.R., CHOI H.T., LIM J.H., LEE I.K., AHN Y.S. Postfire restoration plan for sustainable forest management in
South Korea. Forests, 8 (6), 188, 2017.

6. FAOSTAT. http://www.fao.org/faostat/en/\#data/GF (access 25/01/2018)

7. KIRSCHBAUM M.U.F., WHITEHEAD D., DEAN S.M., BEETS P.N., SHEPHERD J.D., AUSSEIL A.G. Implications of albedo changes following afforestation on the benefits of forests as carbon sinks. Biogeosciences, $\mathbf{8}$ (12), 3687, 2011.

8. KIM G.S., LIM C.H., KIM S.J., LEE J., SON Y., LEE W.K. Effect of national-scale afforestation on forest water supply and soil loss in South Korea, 1971-2010. Sustainability, 9 (6), 1017, 2, 2017.

9. LU C.X., ZHAO T.Y., SHI X.L., CHAO S. Ecological restoration by afforestation may increase groundwater depth and create potentially large ecological and water opportunity costs in arid and semiarid China. Journal of Cleaner Production. 176, 1 March 2018, 1213, 2018.

10. YOSEF G., WALKO R., AVISAR R., TATARINOV F., ROTENBERG E., YAKIR D. Large-scale semiarid afforestation can enhance precipitation and carbon sequestration potential. Scientific Reports, 8 (1), 996, 2018.

11. DAŞDEMIR İ., ŞAHIN A. Economical appraising of plantation alternatives in Bartın region, Journal of Bartın Forestry Faculty, 4 (4), 38, 2002.

12. ŹRÓBEK-RÓŻAŃSKA A., NOWAK A., NOWAK M., ŹRÓBEK S. Financial dilemmas associated with the afforestation of low-productivity farmland in Poland. Forests, 5 (11), 2846, 2014.

13. OZMIȘ M., TOLUNAY A. The Determination of economic value and the trend of society payment of the erosion control services, University of Süleyman Demirel, Journal of Natural Applied Science Institute, 21 (1), 99, 2017 [In Turkish].

14. MUYS B., LUST N., GRANVAL P.H. Effects of Grassland Afforestation with Different Tree Species on Earthworm Communities, Litter Decomposition and Nutrient Status. Soil biology and biochemistry, 24 (12), 1459, 1992.

15. TUNÇTANER K., ÖZEL H.B., ERTEKIN M. Investigation on Adaptation Abilities of Native and Exotic Tree Species Used in The Afforestation Areas in Bartın Region, Journal of Bartın Forestry Faculty, 9 (11), 11, 2007 [In Turkish].

16. VAN ELEGEM B., EMBO T., MUYS B., LUST N. A Methodology to select the best locations for new urban forests using multicriteria analysis. Forestry, 75 (1), 13, 2002.

17. GIMONA A., VAN DER HORST D. mapping hotspots of multiple landscape functions: a case study on farmland afforestation in scotland. Landscape Ecology, 22 (8), 1255, 2007.

18. ÖZEL H.B., KARAYILMAZLAR S., DEMIRCI A. Location Selection for Afforestation Activities Using Mediterranean Pine Selection (Pinus brutia Ten. and Pinus pinea L.) in Bartın Watershed by Analytical Hierarchy Process (AHP) Method, II. National Mediterranean Forest and Environment Symposium "The Future of Mediterranean Forests: Sustainable Society and Environment", Süleyman Demirel University Publisher, Turkey, , 1, 22, 2014 [In Turkish].

19. HUNTER I.R., HOBLEY M., SMALE P. Afforestation of degraded land - pyrrhic victory over economic, social and ecological reality? Ecological Engineering, 10 (1), 97, 1998.

20. IMAL B., BIRBEN U., ÖNER N., ÖZDEN S. SocioEconomic Benefits of Afforestation Project with in The Social Risk Mitigation Project (SRMP), The Research 
Association of Rural Environment and Forestry Publisher, Turkey 32, 2006 [In Turkish].

21. PILLI R., GRASSI G., MORIS J.V., KURZ W.A. Assessing the carbon sink of afforestation with the carbon budget model at the country level: an example for Italy. iForestBiogeosciences and Forestry, 8 (4), 1, 2014.

22. AHLSWEDE B.J., THOMAS R.Q. Community earth system model simulations reveal the relative importance of afforestation and forest management to surface temperature in Eastern North America. Forests, 8 (12), 2, 2017.

23. AKAY A.E. Minimizing total costs of forest roads with computer-aided design model. Sadhana, 31 (5), 621, 2006.

24. DEMIR M. Impacts, management and functional planning criterion of forest road network system in Turkey. Transportation Research Part A: Policy and Practice, 41 (1), 56, 2007.

25. HAYATI E., MAJNOUNIAN B., ABDI E. Qualitative evaluation and optimization of forest road network to minimize total costs and environmental impacts. iForestBiogeosciences and Forestry, 5 (3), 121, 2012.

26. HAVIMO M., MONKONEN P., LOPATIN E., DAHLIN B. Optimising forest road planning to maximise the mobilisation of wood biomass resources in northwest Russia. Biofuels, 8 (4), 501, 2017.

27. GUMUS S., ARICAK B., ENEZ K., ACAR H.H. Analysis of tree damage caused by rockfall at forest road construction works. Croatian Journal of Forest Engineering. 30 (2), 151, 2009.

28. OZTURK T., INAN M., AKGUL M. Environmental damages of forest road construction by bulldozer on steep terrain. African Journal of Biotechnology, 8 (18), 4547, 2009.

29. OZTURK T., INAN M., AKAY A.E. Analysis of tree damage caused by excavated materials at forest road construction in karst region. Croatian Journal of Forest Engineering. 31 (1), 57, 2010.

30. ACAR H.H. Environmental sensitive road planning and transportation techniques in forest engineering. Journal of the Faculty of Forestry of Istanbul University, 66 (2), 710, 2016.

31. LOTFALIAN L., NASIRI M. The distribution and frequency of damage to roadside trees in low-volume road construction. Journal of Forestry Research. 29 (1), 221, 2018.

32. ÇALIŞKAN E. Planning of forest road network and analysis in mountainous area. Life Science Journal, 10 (2), 2456, 2013

33. HAYATI E., MAJNOUNIAN B., ABDI E., SESSIONS J., MAKHDOUM M. An expert-based approach to forest road network planning by combining delphi and spatial multi-criteria evaluation. Environmental Monitoring and Assessment, 185 (2), 1767, 2013a.

34. GULCI S., AKAY A.E. Assessment of ecological passages along road networks within the Mediterranean forest using GIS-based multi criteria evaluation approach. Environmental Monitoring and Assessment, 187 (12), Article No: 779, 2, 2015.

35. LASCHI A., NERI F., BRACHETTI MONTORSELLI N., MARCHI E. A methodological approach exploiting modern techniques for forest road network planning. Croatian Journal of Forest Engineering, 37 (2), 319, 2016.

36. STEFANOVIĆ B., STOJNIĆ D., DANILOVIĆ M. Multi-criteria forest road network planning in fireprone environment: a case study in Serbia. Journal of
Environmental Planning and Management, 59 (5), 911, 2016.

37. CALISKAN E. Planning of environmentally sound forest road route using GIS \& S-MCDM. Šumarski list, 141 (1112), 583, 2017.

38. ACAR H.H., DURSUN E., GULCI S., GUMUS S. Assessment of road network planning by using GIS-based multi-criteria evaluation for conversion of coppice forest to high forest. Fresenius Environmental Bulletin, 26 (3), 2380, 2017.

39. BUGDAY E. Application of artificial neural network system based on anfis using GIS for predicting forest road network suitability mapping. Fresenius Environmental Bulletin, 27 (3), 1656, 2018.

40. ANONYMOUS Doğantepe erozyon kontrolü uygulama projesi. Çankırı Ağaçlandırma ve Toprak Muhafaza Şefliği, General Directorate of Combating Desertification and Erosion, Turkey, 1, 2015 [In Turkish].

41. MOORE I.D., GRAYSON R.B., LADSON A.R. Digital terrain modelling: a review of hydrological, geomorphological, and biological applications. Hydrological Processes, 5 (1), 3, 1991.

42. WILSON J.P., GALLANT J.C. Secondary topographic attributes. terrain analysis: principles and applications, John Wiley\& Sons Publisher, United State of America, 87, 2000.

43. CETIN M. Using GIS analysis to assess urban green space in terms of accessibility: case study in Kutahya. International Journal of Sustainable Development \& World Ecology, 22 (5), 420, 2015.

44. CETIN M., ADIGUZEL F., KAYA O., SAHAP, A. Mapping of bioclimatic comfort for potential planning using GIS in Aydin. Environment, Development and Sustainability, 20 (1), 361, 2018.

45. ALEKSEEV A.S., NIKIFOROV A.A. Effects of topography on the structure and productivity of forest landscapes using 3D modeling in terms of the Lisinsky educational and experimental forest enterprise. Contemporary problems of ecology, 7 (7), 815, 2014.

46. POURGHASEMI H.R., BEHESHTIRAD M., PRADHAN B. A comparative assessment of prediction capabilities of Modified Analytical Hierarchy Process (M-AHP) and Mamdani Fuzzy Logic Models using Netcad-GIS for forest fire susceptibility mapping. Geomatics, Natural Hazards and Risk, 7 (2), 861, 2016.

47. SEZER E.A., NEFESLIOGLU H.A., OSNA T. An expertbased landslide susceptibility mapping (LSM) module developed for Netcad Architect Software. Computers \& Geosciences, 98, 26, 2017.

48. GERDSRI N., KOCAOGLU D.F. Applying the Analytic Hierarchy Process (AHP) to build a strategic framework for technology road mapping. Mathematical and Computer Modelling, 46 (7-8), 1071, 2007.

49. AHMED N.G., ASMAEL N.M. A GIS-assisted optimal Baghdad metro route selection based on multi criteria decision making. Journal of Engineering and Development, 19 (06), 44, 2015

50. BARIĆ D., PILKO H., STRUJIĆ J. An analytic hierarchy process model to evaluate road section design. Transport, 31 (3), 312, 2016

51. KUŠAR M., ŠELIH J. Determination of refurbishment priorities for passes on road network level. Tehnički Vjesnik, 24 (4), 1129, 2017.

52. KUMAR Y., PANCHAL S., ASHISH A., SINGH B. P. Feasibility study of railway line in hilly region using GIS. 
International Journal of Online Engineering (iJOE), 13 (08), 183, 2017.

53. NAGHDI R., BABAPOUR R. Planning and evaluating of forest roads network with respect to environmental aspects via GIS application (Case Study: Shafaroud Forest, Northern Iran). In Environmental and Computer Science-2009 (IEEE), IEEE Publisher, Iran, 1, 424, 2009.

54. GHAJAR I., NAJAFI A., ALI TORABI S., KHAMEHCHIYAN M., BOSTON K. An adaptive network-based fuzzy inference system for rock share estimation in forest road construction. Croatian Journal of Forest Engineering: Journal for Theory and Application of Forestry Engineering, 33 (2), 313, 2012.

55. NORIZAH K., MOHD HASMADI I. Developing priorities and ranking for suitable forest road allocation using Analytic Hierarchy Process (AHP) in Peninsular Malaysia. Sains Malaysiana, 41 (10), 1177, 2012.

56. HAYATI E., ABDI E., MAJNOUNIAN B., MAKHDOM M. Application of sensitivity analysis in forest road networks planning and assessment. Journal of Agricultural Science and Technology. 15 (1), 781, 2013b.

57. BABAPOUR R., NAGHDI R., SALEHI A., GHAJAR I. A decision support system for allocation of mountain forest roads based on ground stability. Arabian Journal for Science and Engineering, 39 (1), 199, 2014.

58. GUMUS S. An evaluation of stakeholder perception differences in forest road assessment factors using the Analytic Hierarchy Process (AHP). Forests, 8 (5), 165, pp. 2-9, 2017.

59. NEFESLIOGLU H.A., SEZER E.A., GOKCEOGLU C., AYAS Z. A Modified Analytical Hierarchy Process (M-AHP) approach for decision support systems in natural hazard assessments. Computers \& Geosciences, 59, 1, 2013.

60. GOKCEOGLU C., NEFESLIOGLU H.A., TANYILDIZ N. A decision support system suggestion for the optimum railway route selection. In Engineering Geology for Society and Territory-Volume 5, Springer Press, Netherland, 331, 2015.
61. ZADEH L.A. Information and Control. Fuzzy Sets, Information and Control, 8 (3), 338, 1965.

62. AKGUN A., SEZER E.A., NEFESLIOGLU H.A., GOKCEOGLU C., PRADHAN B. An easy to use MATLAB Program (MamLand) for the assessment of landslide susceptibility using a Mamdani Fuzzy Algorithm. Computer Geoscience 38 (1), 23, 2012.

63. POURGHASEMI H.R., PRADHAN B., GOKCEOGLU C. Application of Fuzzy Logic and Analytical Hierarchy Process (AHP) to landslide susceptibility mapping at Haraz Watershed, Iran. Natural Hazards, 63 (2), 965, 2012.

64. BALEZENTIENE L., STREIMIKIENE D., BALEZENTIS T. Fuzzy decision support methodology for sustainable energy crop selection. Renewable and Sustainable Energy Reviews, 17, 83, 2013.

65. SEIBERT J., STENDAHL J., SØRENSEN R. Topographical influences on soil properties in Boreal Forests. Geoderma, 141 (1-2), 139, 2007.

66. KOLKA R.K., SMIDT M.F. Effects of forest road amelioration techniques on soil bulk density, surface runoff, sediment transport, soil moisture and seedling growth. Forest Ecology and Management, 202 (1-3), 313, 2004.

67. JAAFARI A., NAJAFI A., POURGHASEMI H.R., REZAEIAN J., SATTARIAN A. GIS-based frequency ratio and index of entropy models for landslide susceptibility assessment in the Caspian Forest, Northern Iran. International Journal of Environmental Science and Technology, 11 (4), 909, 2014.

68. PRADHAN B. Use of GIS-based fuzzy logic relations and its cross application to produce landslide susceptibility maps in three test areas in Malaysia. Environmental Earth Sciences, 63 (2), 329, 2011.

69. POURGHASEMI H.R., ROSSI M. Landslide susceptibility modeling in a landslide prone area in Mazandarn Province, North of Iran: A comparison between GLM, GAM, MARS, and M-AHP Methods. Theoretical and Applied Climatology, 130 (1-2), 609, 2017. 
